\title{
Tendency and seasonality of suicide in Chihuahua, México. A retrospective analysis from 2008 to 2018
}

\author{
Montserrat Fernández-López, ${ }^{,}$Rosa Ivonne Hernández-Montes, ${ }^{\prime}$ Sofía Álvarez Reza, ${ }^{\prime}$ Luis Alberto Flores-Olivares'
}

Instituto Chihuahuense de Salud Mental, Chihuahua, Chihuahua, México.

\section{Correspondence:} Luis Alberto Flores-Olivares Instituto Chihuahuense de Salud Mental.

Calle Aldama 1502

Col. Centro,

31000, Chihuahua, Chihuahua, México.

Phone: 614 429-3300 ext. 15132

Email: ichisam.sp@gmail.com

Received: 21 February 2020

Accepted: 25 August 2020

Citation:

Fernández-López, M., Hernández-Montes, R. I., Álvarez Reza, S. \& Flores-Olivares, L. A. (2021). Tendency and seasonality of suicide in Chihuahua, México. A retrospective analysis from 2008 to 2018 . Salud Mental, 44(2), 43-52

DOI: $10.17711 /$ SM. 0185-3325.2021.008

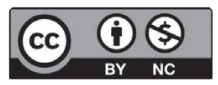

\begin{abstract}
Introduction. Suicide has shown an international and national trend to increase, mainly in young people, together with seasonal behavior associated with high temperatures. Although Chihuahua saw the highest number of suicides and suicide attempts in 2016, there are no studies documenting their seasonal and trend behavior. Objective. This study sought to analyze the trend and seasonality of completed suicides in the state of Chihuahua from 2008 to 2018. Method. The number of deaths from intentionally self-inflicted injuries was obtained from INEGI. The absolute suicide rate was estimated, and a time series model applied to identify its trend and seasonality. In addition, environmental temperature was used as a predictor variable for the number of suicides through a Poisson model. Results. A trend was found in the completed suicide rate from 2008 to 2018 in men and women, both separately and together (stationary $\mathrm{R}^{2} .73, .66$ and .69 , respectively), together with seasonality in both sexes $(p<.002)$, with the highest figures being recorded in June and July. An increase of 1,028 suicides was found for every $1^{\circ} \mathrm{C}$ rise in temperature. In the 10-24 and 25-34 age groups, a linear increase in the suicide rate was observed during the period studied $\left(\mathrm{R}^{2}>.7, p=.001\right)$. Discussion and conclusion. Between 2008 and 2018, the suicide rate increased in the state of Chihuahua, mainly among those aged between 10 and 34 . Moreover, suicide rates tend to increase during the months of June and July because of temperature.
\end{abstract}

Keywords: Mental health, suicide, time series, epidemiology.

\section{RESUMEN}

Introducción. El suicidio ha presentado una tendencia a la alta a nivel internacional y nacional, principalmente en jóvenes, y un comportamiento estacional, asociado a altas temperaturas. Aunque Chihuahua presentó la mayor cantidad de suicidios e intentos de suicidio durante 2016; no hay estudios que evidencien su comportamiento tendencial y estacional. Objetivo. El objetivo fue analizar la tendencia y estacionalidad de suicidios consumados en el estado de Chihuahua de 2008 a 2018. Método. Se obtuvieron las defunciones por lesiones autoinfligidas intencionalmente del repositorio del INEGI. Se estimó la tasa de suicidio absoluta y se aplicó un modelo de series de tiempo para identificar su tendencia y estacionalidad; además, se utilizó la temperatura ambiental como variable predictora en el número de suicidios por medio de un modelo Poisson. Resultados. Se encontró una tendencia en la tasa de suicidios consumados de 2008 a 2018 en hombres, mujeres y en conjunto ( $R^{2}$ estacionaria .73 , .66 y .69, respectivamente); y estacionalidad en ambos sexos $(p<.002)$, donde los mayores registros fueron en junio y julio. Se encontró una asociación en un incremento de 1,028 suicidios por cada incremento de $1^{\circ} \mathrm{C}$ de la temperatura. En los grupos etarios de 10-24 y 25-34 se observó un incremento lineal en la tasa de suicidio durante el periodo estudiado $\left(\mathrm{R}^{2}>.7, p=.001\right)$. Discusión y conclusión. De 2008 a 2018, la tasa de suicidios se ha incrementado en el estado de Chihuahua, principalmente entre los 10 y 34 años de edad. Además, la tasa de suicidio tiende a incrementarse durante los meses de junio y julio, asociándose a la temperatura.

Palabras clave: Salud mental, suicidio, series de tiempo, epidemiología. 


\section{INTRODUCTION}

Suicide is a multifactorial phenomenon, whose main determinants include biological, sociocultural, economic, familial, and intrapersonal aspects, chronic-degenerative diseases, and mental disorders (WHO, 2018a). It is currently recognized as a public health problem that is the third leading cause of death in the population aged 15 to 44 worldwide (Bachmann, 2018).

In 2016, the World Health Organization (WHO) reported a global suicide rate of 10.6 per 100,000 inhabitants, 7.7 in women and 13.5 in men, representing approximately 800,000 suicides per year, with one suicide estimated to occur every 40 seconds (WHO, 2018a).

A $275 \%$ rise in the prevalence of suicide was reported from 1970 to 2007 in Mexico, which has seen a linear increase in suicide rates since 1984 (Borges, Orozco, Benjet, \& Medina-Mora, 2010). Between 2000 and 2013, 64,298 suicide cases were registered in Mexico, where the rate increased in both sexes, from 5.95 to 8.12 in men and from 1.06 to 1.73 in women, with a male-to-female ratio of 4.5:1 (Fernández-Niño et al., 2016). The most recent data published by the Instituto Nacional de Estadística y Geografía [National Institute of Statistic and Geography] indicated a national rate of 5.1 per 100,000 inhabitants (INEGI, 2018).

This increase in suicide rates has been accompanied by the seasonal factor, with the highest suicide rates being found in the summer months (Swade \& Coppen, 1980). A non-systematic review observed a significant seasonal effect in suicide rates in various studies undertaken in different countries, where suicides peaked in the spring and summer months (Ajdacic-Gross, Bopp, Ring, Gutzwiller, \& Rossler, 2010). A recent study in Mexico found that from 2000 to 2013 May was the month with the highest number of suicides, while February had the lowest number in both sexes (Fernández-Niño et al., 2016).

Various studies based on analyses of Poisson regression models have estimated the increase in suicide in relation to environmental temperature. In England and Wales, after a one-degree temperature rise above $18^{\circ} \mathrm{C}$, suicide risk increased from $3.8 \%$ to $5.0 \%$ (Page, Hajat, \& Kovats, 2007), while in South Korea, high temperatures were associated with a relative risk of an increase in the number of suicides (Kalkstein, Belorid, Dixon, Kim, \& Bremer, 2019).

In addition, as has been reported in the literature, environmental temperature is associated with thermal stress, a higher risk of infectious diseases, and an increase in natural disasters such as floods or, conversely, droughts and forest fires (McMichael, Woodruff, \& Hales, 2006).

Chihuahua is one of the states in Mexico that has registered higher temperatures during the summer months in recent years (CONAGUA, 2020). In addition, it is a subtropical region, $73 \%$ of which has a dry or "semi-dry" climate.

In 2016, Chihuahua had the highest suicide rate nationwide, with 11.4 per 100,000 inhabitants. Recent data from the Encuesta Nacional de Consumo de Drogas, Alcohol y Tabaco [National Survey of Dryg, Alcohol and Tobacco Use] indicate that during that same year it also displayed the highest prevalence of suicide attempts in the country (Borges et al., 2019). The objectives of the present study were therefore to analyze the seasonal behavior of completed suicides in the state of Chihuahua and the trend in suicide rates by sex and age group between 2008 and 2018 to generate updated information that will make it possible to implement more effective prevention strategies in the future.

\section{METHOD}

This study was undertaken with data on deaths by suicide obtained from statistics from the Instituto Nacional de Estadística y Geografía [INEGI, 2001; National Institute of Statistic and Geography] (INEGI, 2001) between 2008 and 2018 in the state of Chihuahua. The death registration process is completed when a death certificate is completed and issued by the civil registry office. In the time covered by this study, 3,572 records of completed suicide were presented. Data collection involved obtaining the number of intentional self-inflicted injuries through an examination of the detailed causes of the ICD-10 (X605 to X849) in the accidental and violent deaths section of mortality rates.

Moreover, variables such as the month and year of occurrence, sex, and age were obtained, which were classified into seven age groups in keeping with other similar studies (Shah, 2012; Shah \& Coupe, 2009):10-24, 25-34, 35-44, 45$54,55-64,65-74$ and 75 or over, educational attainment, suicide method, marital status, being an indigenous language speaker, urban or rural residence and economic activity, and whether the person who committed suicide was employed. Data on being an indigenous language speaker, economic activity, and suicide method are available as of 2012. For the remaining variables, data are available from 2008 onwards.

This study also considered the daily average temperature record by weather station, which in turn was averaged per month to be used as a covariate regarding the number of suicides. Temperature data were obtained from the Servicio Meteorológico Nacional [National Meteorological Service] from the statistical climate information database.

\section{Statistical analysis}

Suicide rates standardized by sex and age group were calculated for each of the months and years of study for every 100,000 inhabitants, based on population projections by the Consejo Nacional de Población [CONAPO, National Population Council] using the 2005 and 2010 population censuses.

In the categorical variables such as age group, sex, educational attainment, marital status, being an indigenous language speaker, economic activity, and suicide method, a mul- 
tivariate correspondence analysis was performed. Previously, the relationship of these variables was analyzed through a simple correspondence analysis where the $p$ value of chi squared $\leq .05$ was considered a significant relationship.

Since data on being an indigenous language speaker and suicide method are only available as of 2012, multiple correspondence analyses were undertaken on the years when only some of the variables were available.
A univariate analysis of time series was carried out in which the suicide trend from 2008 to 2018 and the LjungBox test were determined to establish the self-correlation of observations in that period. The seasonality factor expressed as a percentage and the Dickey-Fuller test were used to establish the seasonality of the observations. In addition, a Poisson regression model was performed to establish the association between temperature and the number of

Table 1

Accumulated percentage of sociodemographic, socioeconomic, sociocultural, variables, and suicide methods in the state of Chihuahua 2008-2018

\begin{tabular}{|c|c|c|c|c|c|c|c|c|c|c|c|c|}
\hline & $\begin{array}{c}2008 \\
(n=228) \\
\end{array}$ & $\begin{array}{c}2009 \\
(n=245) \\
\end{array}$ & $\begin{array}{c}2010 \\
(n=234) \\
\end{array}$ & $\begin{array}{c}2011 \\
(n=292) \\
\end{array}$ & $\begin{array}{c}2012 \\
(n=264) \\
\end{array}$ & $\begin{array}{c}2013 \\
(n=313) \\
\end{array}$ & $\begin{array}{c}2014 \\
(n=327) \\
\end{array}$ & $\begin{array}{c}2015 \\
(n=422) \\
\end{array}$ & $\begin{array}{c}2016 \\
(n=439) \\
\end{array}$ & $\begin{array}{c}2017 \\
(n=410) \\
\end{array}$ & $\begin{array}{c}2018 \\
(n=398) \\
\end{array}$ & $\begin{array}{c}\text { Total } \\
(n=3174)\end{array}$ \\
\hline \multicolumn{13}{|l|}{ Marital Status } \\
\hline Under 12 & $0 \%$ & $0 \%$ & $0 \%$ & $1 \%$ & $1 \%$ & $1 \%$ & $0 \%$ & $0 \%$ & $0 \%$ & $0 \%$ & $0 \%$ & $0 \%$ \\
\hline Single & $32 \%$ & $42 \%$ & $38 \%$ & $35 \%$ & $29 \%$ & $35 \%$ & $31 \%$ & $28 \%$ & $36 \%$ & $35 \%$ & $39 \%$ & $34 \%$ \\
\hline Married & $28 \%$ & $31 \%$ & $30 \%$ & $26 \%$ & $26 \%$ & $23 \%$ & $27 \%$ & $23 \%$ & $20 \%$ & $21 \%$ & $20 \%$ & $25 \%$ \\
\hline Partnered & $24 \%$ & $18 \%$ & $18 \%$ & $15 \%$ & $15 \%$ & $18 \%$ & $16 \%$ & $20 \%$ & $15 \%$ & $18 \%$ & $22 \%$ & $18 \%$ \\
\hline Separated & $0 \%$ & $0 \%$ & $0 \%$ & $0 \%$ & $2 \%$ & $1 \%$ & $2 \%$ & $1 \%$ & $1 \%$ & $0 \%$ & $0 \%$ & $1 \%$ \\
\hline Divorced & $6 \%$ & $4 \%$ & $2 \%$ & $3 \%$ & $3 \%$ & $3 \%$ & $3 \%$ & $3 \%$ & $4 \%$ & $3 \%$ & $3 \%$ & $3 \%$ \\
\hline Widowed & $4 \%$ & $2 \%$ & $4 \%$ & $4 \%$ & $6 \%$ & $1 \%$ & $2 \%$ & $3 \%$ & $2 \%$ & $3 \%$ & $3 \%$ & $3 \%$ \\
\hline Not specified & $6 \%$ & $4 \%$ & $8 \%$ & $16 \%$ & $19 \%$ & $19 \%$ & $20 \%$ & $21 \%$ & $22 \%$ & $19 \%$ & $13 \%$ & $17 \%$ \\
\hline Total & $100 \%$ & $100 \%$ & $100 \%$ & $100 \%$ & $100 \%$ & $100 \%$ & $100 \%$ & $100 \%$ & $100 \%$ & $100 \%$ & $100 \%$ & $100 \%$ \\
\hline \multicolumn{13}{|c|}{ Usual place of residence-urban/rural } \\
\hline Urban area & $71 \%$ & $81 \%$ & $76 \%$ & $73 \%$ & $67 \%$ & $77 \%$ & $75 \%$ & $68 \%$ & $75 \%$ & $75 \%$ & $77 \%$ & $74 \%$ \\
\hline Rural area & $28 \%$ & $17 \%$ & $21 \%$ & $21 \%$ & $22 \%$ & $19 \%$ & $22 \%$ & $20 \%$ & $19 \%$ & $22 \%$ & $14 \%$ & $21 \%$ \\
\hline Not specified & $1 \%$ & $2 \%$ & $3 \%$ & $6 \%$ & $11 \%$ & $4 \%$ & $3 \%$ & $12 \%$ & $6 \%$ & $2 \%$ & $9 \%$ & $5 \%$ \\
\hline Total & $100 \%$ & $100 \%$ & $100 \%$ & $100 \%$ & $100 \%$ & $100 \%$ & $100 \%$ & $100 \%$ & $100 \%$ & $100 \%$ & $100 \%$ & $100 \%$ \\
\hline \multicolumn{13}{|l|}{ Educational attainment } \\
\hline No schooling & $6 \%$ & $3 \%$ & $4 \%$ & $6 \%$ & $3 \%$ & $13 \%$ & $9 \%$ & $7 \%$ & $9 \%$ & $8 \%$ & $14 \%$ & $7 \%$ \\
\hline Elementary & $45 \%$ & $46 \%$ & $45 \%$ & $38 \%$ & $37 \%$ & $25 \%$ & $34 \%$ & $35 \%$ & $34 \%$ & $29 \%$ & $27 \%$ & $35 \%$ \\
\hline Junior high school & $24 \%$ & $23 \%$ & $24 \%$ & $24 \%$ & $27 \%$ & $28 \%$ & $25 \%$ & $26 \%$ & $27 \%$ & $28 \%$ & $27 \%$ & $26 \%$ \\
\hline Senior high school & $8 \%$ & $11 \%$ & $12 \%$ & $12 \%$ & $13 \%$ & $14 \%$ & $18 \%$ & $11 \%$ & $14 \%$ & $16 \%$ & $13 \%$ & $10 \%$ \\
\hline Professional & $7 \%$ & $7 \%$ & $7 \%$ & $4 \%$ & $4 \%$ & $8 \%$ & $5 \%$ & $6 \%$ & $8 \%$ & $6 \%$ & $8 \%$ & $7 \%$ \\
\hline Not specified & $11 \%$ & $11 \%$ & $8 \%$ & $18 \%$ & $17 \%$ & $9 \%$ & $8 \%$ & $15 \%$ & $8 \%$ & $13 \%$ & $11 \%$ & $12 \%$ \\
\hline Total & $100 \%$ & $100 \%$ & $100 \%$ & $100 \%$ & $100 \%$ & $100 \%$ & $100 \%$ & $100 \%$ & $100 \%$ & $100 \%$ & $100 \%$ & $100 \%$ \\
\hline \multicolumn{13}{|c|}{ Indigenous language speaker } \\
\hline $\begin{array}{l}\text { Indigenous language } \\
\text { speaker }\end{array}$ & - & - & - & - & $4 \%$ & $4 \%$ & $6 \%$ & $5 \%$ & $6 \%$ & $7 \%$ & $9 \%$ & $6 \%$ \\
\hline $\begin{array}{l}\text { Non indigenous lan- } \\
\text { guage speaker }\end{array}$ & - & - & - & - & $26 \%$ & $20 \%$ & $26 \%$ & $18 \%$ & $21 \%$ & $31 \%$ & $48 \%$ & $27 \%$ \\
\hline Not specified & - & - & - & - & $70 \%$ & $76 \%$ & $69 \%$ & $77 \%$ & $73 \%$ & $61 \%$ & $43 \%$ & $67 \%$ \\
\hline Total & - & - & - & - & $100 \%$ & $100 \%$ & $100 \%$ & $100 \%$ & $100 \%$ & $100 \%$ & $100 \%$ & $100 \%$ \\
\hline \multicolumn{13}{|l|}{ Method } \\
\hline Poisoning & - & - & - & - & $7 \%$ & $8 \%$ & $7 \%$ & $5 \%$ & $5 \%$ & $7 \%$ & $5 \%$ & $7 \%$ \\
\hline Hanging & - & - & - & - & $71 \%$ & $71 \%$ & $70 \%$ & $69 \%$ & $76 \%$ & $67 \%$ & $74 \%$ & $71 \%$ \\
\hline Firearm & - & - & - & - & $20 \%$ & $16 \%$ & $16 \%$ & $13 \%$ & $12 \%$ & $13 \%$ & $12 \%$ & $14 \%$ \\
\hline Wounding & - & - & - & - & $1 \%$ & $1 \%$ & $1 \%$ & $1 \%$ & $1 \%$ & $2 \%$ & $1 \%$ & $1 \%$ \\
\hline Jumping from height & - & - & - & - & $0 \%$ & $1 \%$ & $1 \%$ & $1 \%$ & $1 \%$ & $1 \%$ & $1 \%$ & $1 \%$ \\
\hline Not specified & - & - & - & - & $1 \%$ & $3 \%$ & $5 \%$ & $10 \%$ & $5 \%$ & $10 \%$ & $8 \%$ & $6 \%$ \\
\hline Total & - & - & - & - & $100 \%$ & $100 \%$ & $100 \%$ & $100 \%$ & $100 \%$ & $100 \%$ & $100 \%$ & $100 \%$ \\
\hline
\end{tabular}

Source: Compiled by the author with data from the Instituto Nacional de Estadística y Geografía [National Survey of Statistics and Geography]. 
Table 2

Suicide rate by sex and men/women ratio in the state of Chihuahua 2008-2018

\begin{tabular}{llccc}
\hline Year & Men & Women & Total & Ratio \\
\hline 2008 & 10.7 & 2.7 & 6.7 & 4.0 \\
2009 & 12.1 & 2.2 & 7.1 & 5.5 \\
2010 & 11.8 & 1.8 & 6.8 & 6.6 \\
2011 & 14.1 & 2.7 & 8.3 & 5.3 \\
2012 & 12.6 & 2.4 & 7.5 & 5.2 \\
2013 & 14.2 & 3.4 & 8.8 & 4.2 \\
2014 & 14.0 & 4.3 & 9.1 & 3.3 \\
2015 & 18.2 & 5.3 & 11.7 & 3.4 \\
2016 & 18.8 & 5.4 & 12.0 & 3.5 \\
2017 & 17.5 & 4.8 & 11.1 & 3.7 \\
2018 & 17.5 & 3.6 & 10.4 & 4.9 \\
\hline
\end{tabular}

Source: Compiled by the author with data from the Instituto Nacional de Estadística y Geografía [National Survey of Statistics and Geography].

suicides by sex. Lastly, to analyze the relationship between the suicide rate and age groups, Spearman's rho coefficient was determined, as suggested in other studies (Shah, 2007; Shah \& Coupe, 2009), and a time series and linear regression analysis was undertaken to analyze the possible increase in the suicide rate in each of the age groups.

All tests were performed with a 95\% confidence interval.

\section{Ethical considerations}

This study is based on the INEGI Terms of Free Use of Information.

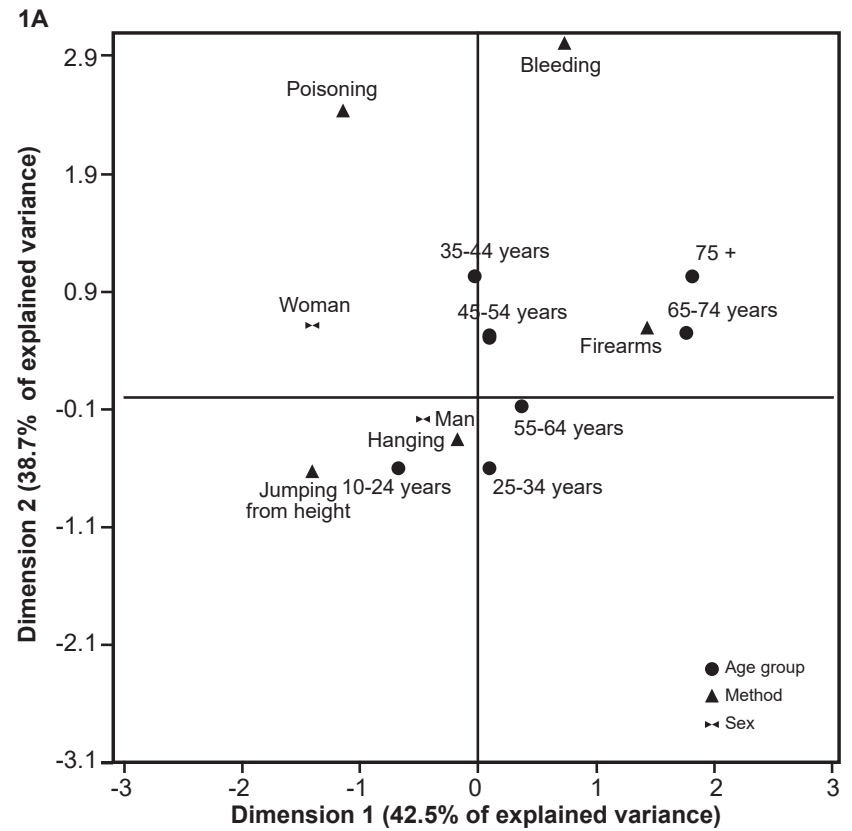

\section{RESULTS}

During the period from 2008 to 2018, a total of 3,572 suicides occurred in the state of Chihuahua, $80 \%$ of which corresponded to men and $20 \%$ to women. The years with the highest suicide rates were 2015 (11.7), 2016 (12.0), and 2017 (11.1), with 422,439 , and 410 completed suicides, respectively.

Regarding educational attainment, $68 \%$ of those who committed suicide had completed high school or less. As for marital status, $34 \%$ were single, $25 \%$ married, and $18 \%$ were partnered, while the most common suicide method was poisoning with $71 \%$ and firearms with $14 \%$. Table 1 shows the remaining socioeconomic variables from 2008 to 2018 .

Regarding gender, a suicide rate of 14.5 in men and 3.5 in women was found during the period studied, with a maleto-female ratio of suicides of 4:1 (Table 2).

A multiple correspondence analysis was performed between the variables of sex, age group, marital status, and suicide method with 2,568 valid cases (between 2012 and 2018), which comprised two dimensions, accounting for $77.5 \%$ of the variance. Figure 1a shows a link between the categories of people ages 10 to 24 and 25 to 34 and the suspension/hanging and jumping from a height method (the former being associated more with men and the latter with women). A second association between categories was found between married and divorced people ages 35 to 44 and 45 to 54 and wounding and poisoning, mainly in women, while a third was found between the use of firearms and men over 65 .

A second analysis of multiple correspondence between being an indigenous language speaker, economic status, ed-

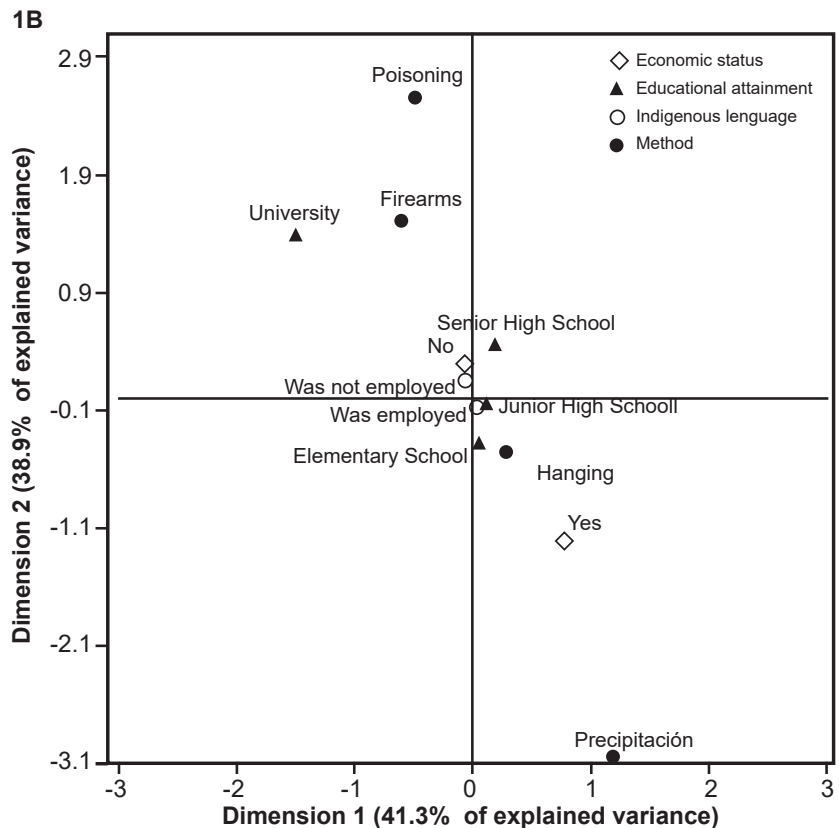

Figure 1. Analysis of correspondence between sex, age group, marital status, and suicide method (1A) and between economic status, educational attainment, being an indigenous language speaker and suicide method, based on suicides completed between 2012 and 2018. 


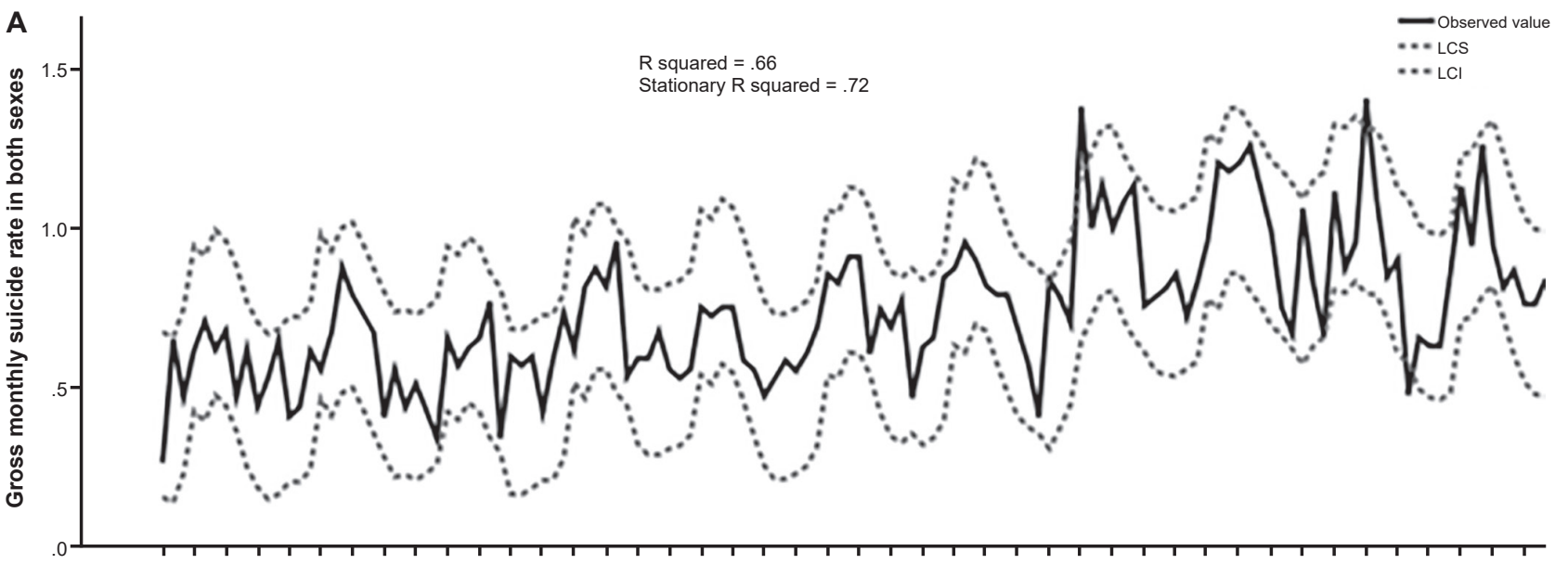

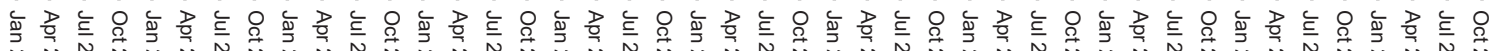

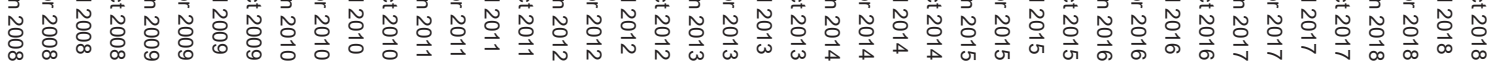
Month and year
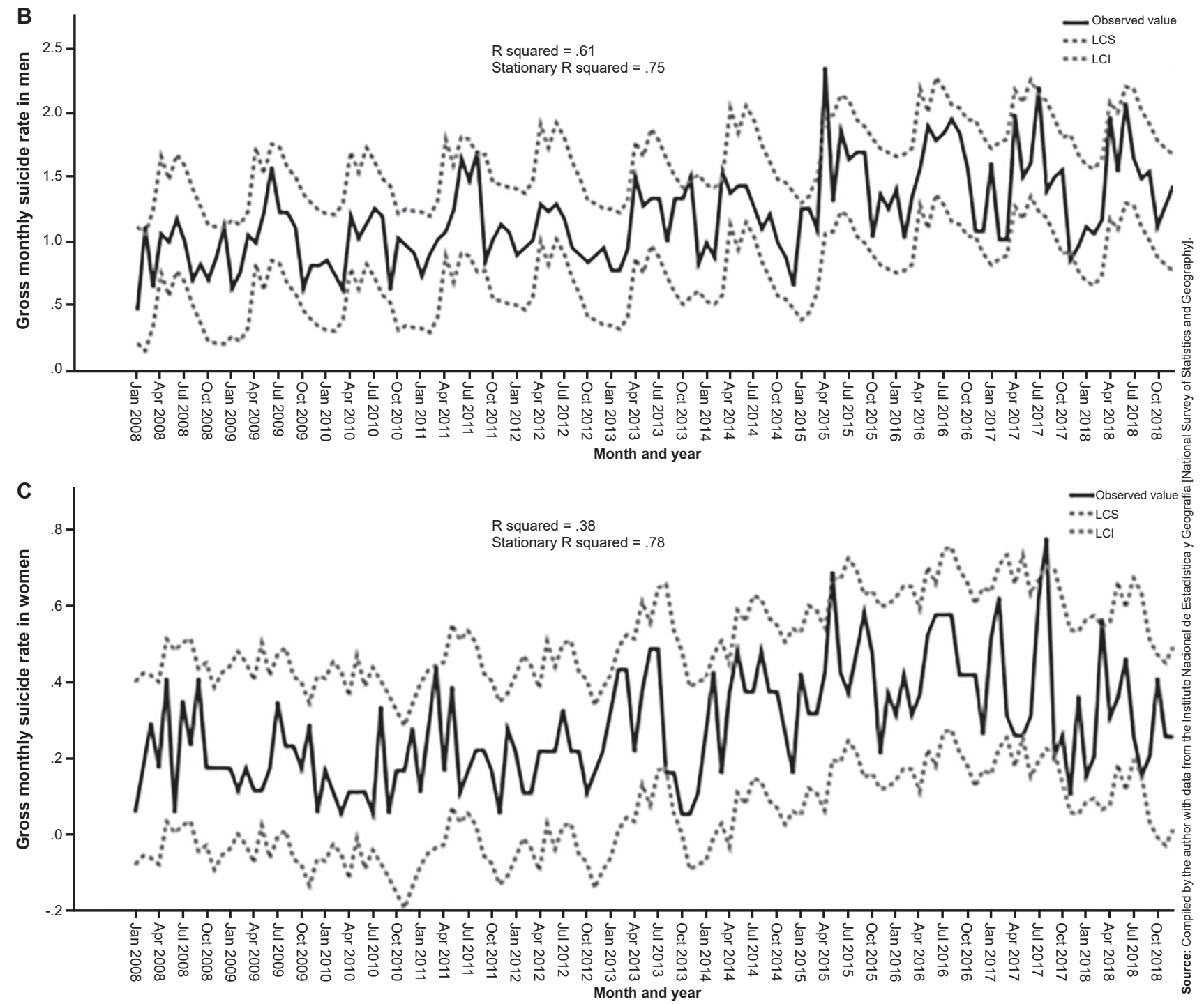

Figure 2. Monthly suicide rate trend (per 100,000 inhabitants) from 2008 to 2018 in the state of Chihuahua. A) Total, B) Men, C) Women. 95\% Confidence intervals. 
Table 3

Average suicide rate by month and seasonality factor in relation to suicide rate in the state of Chihuahua 2008-2018

\begin{tabular}{|c|c|c|c|c|c|c|}
\hline \multirow[b]{2}{*}{ Month } & \multicolumn{2}{|r|}{ Men } & \multicolumn{2}{|c|}{ Women } & \multicolumn{2}{|r|}{ Total } \\
\hline & Rate $(X \pm S D)$ & SF\% (Cl) & Rate $(X \pm S D)$ & SF\% (Cl) & Rate $(X \pm S D)$ & SF\% (Cl) \\
\hline January & $.98 \pm .34$ & $83.6[74.3,92.7]$ & $.25 \pm .14$ & $95.7[75.8,115.6]$ & $.61 \pm .23$ & $84.0[74.1,93.9]$ \\
\hline February & $.96 \pm .16$ & $77.4[71.3,83.5]$ & $.29 \pm .17$ & $99.9[71.4,128.4]$ & $.62 \pm .13$ & $82.4[77.2,88.7]$ \\
\hline March & $1.05 \pm .27$ & $88.3[77.0,100.3]$ & $.29 \pm .15$ & $97.1[54.6,139.6]$ & $.66 \pm .16$ & $92.2[80.4,103.9]$ \\
\hline April & $1.49 \pm .44$ & $122.6[105.9,139.3]$ & $.25 \pm .11$ & $88.6[73.4,103.8]$ & $.86 \pm .26$ & $115.2[101.2,129.2]$ \\
\hline May & $1.34 \pm .25$ & $113.3[107.0,119.6]$ & $.36 \pm .18$ & $120.2[92.3,148.1]$ & $.84 \pm .18$ & $114.0[107.6,120.3]$ \\
\hline June & $1.54 \pm .29$ & $127.9[117.4,138.3]$ & $.30 \pm .18$ & $109.3[83.5,135.1]$ & $.91 \pm .21$ & $124.2[115.8,133.7]$ \\
\hline July & $1.46 \pm .35$ & $119.1[109.1,129.1]$ & $.36 \pm .17$ & $129.6[93.6,165.3]$ & $.90 \pm .23$ & $119.8[109.4,130.2]$ \\
\hline August & $1.31 \pm .37$ & $107.8[92.8,123.0]$ & $.35 \pm .20$ & $130.0[90.3,169.7]$ & $.83 \pm .24$ & $113.0[98.1,127.6]$ \\
\hline September & $1.22 \pm .40$ & $100.6[87.4,113.8]$ & $.28 \pm .15$ & $99.3[68.3,130.3]$ & $.75 \pm .24$ & $100.5[87.3,113.7]$ \\
\hline October & $1.08 \pm .31$ & $90.2[78.67,101.7]$ & $.25 \pm .14$ & $85.0[64.7,105.3]$ & $.66 \pm .18$ & $87.6[79.1,95.7]$ \\
\hline November & $1.06 \pm .23$ & $87.6[75.1,100.0]$ & $.20 \pm .11$ & $64.3[33.5,95.1]$ & $.62 \pm .11$ & $85.4[75.2,95.6]$ \\
\hline December & $1.01 \pm .22$ & $81.6[68.5,94.7]$ & $.23 \pm .10$ & $81.0[52.6,109.4]$ & $.62 \pm .14$ & $81.6[68.1,95.5]$ \\
\hline
\end{tabular}

Notes: $\mathrm{X}=$ Mean. $\mathrm{SD}=$ Standard deviation. SF = Seasonality Factor. $\mathrm{Cl}=$ Confidence Interval.

Source: Compiled by the author with data from the Instituto Nacional de Estadística y Geografía [National Survey of Statistics and Geography].

ucational attainment, and suicide method explained $80.2 \%$ of the variance and revealed the association between committing suicide by jumping from height, being an indigenous language speaker, and only having completed elementary school. A second association was observed between people with a university degree and committing suicide using firearms or poisoning (Figure 1b).

The time series analysis revealed a trend in the increase in suicide rates from 2008 to 2018 in men and women, both separately and together, with a stationary $\mathrm{R}^{2}$ of $.75, .78$, and .72 , respectively $(p<.01)$; graphs are shown in Figure 2. Moreover, according to the Box-Ljung test, randomness and independence of data were observed for the models of men and for the study universe $(p>.43)$.

Likewise, based on the Dickey-Fuller test, seasonality was observed in the suicide rate ( $p=.002$ in men, $p=.001$ in women, and $p=.009$ overall). Table 3 shows the percentage of the seasonality factor by sex, where the highest suicide rate in men according to the seasonality factor occurred in the months of April, June, and July, when it increased by $13 \%$, $28 \%$, and $19 \%$, respectively. Conversely, suicide rates in women increased in May, July, and August by $20 \%, 30 \%$ and $30 \%$, respectively. For the two sexes combined, it increased by $24 \%$ in June and $20 \%$ in July. Figure 3 shows the diagram of the seasonality factor for each sex and the two combined.

An analysis of the effect of temperature on the number of suicides in the two sexes combined through an analysis with a Poisson regression model revealed an association between temperature and the number of suicides from 2008 to 2018. For every one-degree Celsius increase, the risk of suicide rose by 1,028 in the two sexes combined, with 1,029 in men and 1,024 in women. Table 4 provides a summary of the model.

The highest number of completed suicides by age group occurred between the ages of 10 and $24(n=1065)$ and between 25 and $34(n=765)$, and 35 and $44(n=649)$. Table 5 shows the completed suicides and the suicide rate by age group and sex during the study period.

Figure 4 illustrates the association between categorical age and suicide rate. An inverse correlation was found in women with a Spearman correlation coefficient of -.92 $(p=.003)$, while no relationship was found in men or in the two sexes combined $(\mathrm{r}=.64, p=.119$ and $\mathrm{r}=.36, p=.432$, respectively).

The suicide rate trend was observed in the group aged 10 to 24 . Between 2008 and 2018, it increased from 9.3 to 18.5 in men and from 3.6 to 5.1 in women. This increase was evidenced by an $\mathrm{R}^{2}$ value of .76 and .52 , respectively $(p<.001)$. In the group aged 25 to 34 , a linear increase in suicide rates was also observed in men from 14.7 to 30.4 and in women from 4.0 to 6.7 , with an $\mathrm{R}^{2}$ value of .73 and $.72(p<.001)$, respectively. Finally, in the group aged 35 to 44 , the suicide rate for men increased from 15.8 to 23.4 , with an $\mathrm{R}^{2}$ of .56 $(p<.001)$. Figure 5 shows the linear relationship of each of these age groups.

\section{DISCUSSION AND CONCLUSION}

This study is the first to provide information on the behavior of the suicide phenomenon in the state of Chihuahua, where an upward trend in suicide rates was observed from 2008 to 2018, accompanied by the seasonal variation factor, with cyclical peaks during the spring and summer months. This increase in completed suicides in recent years is a phenomenon that has been reported in the literature. In Mexico, Fernández-Niño et al. (2016) found increases in suicide rates for both sexes from 2000 to 2013. This increase is not exclusive to recent years. Borges, Rosovsky, Caballero, and 


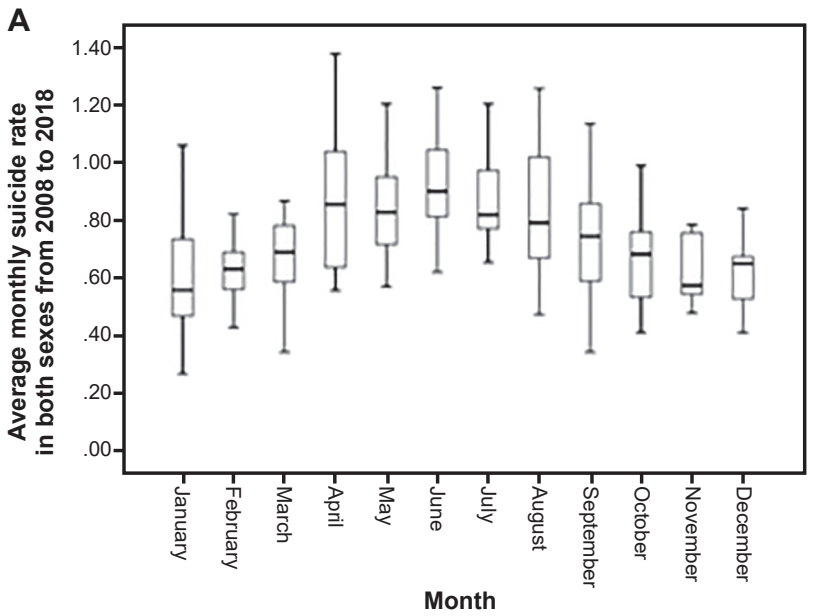

B
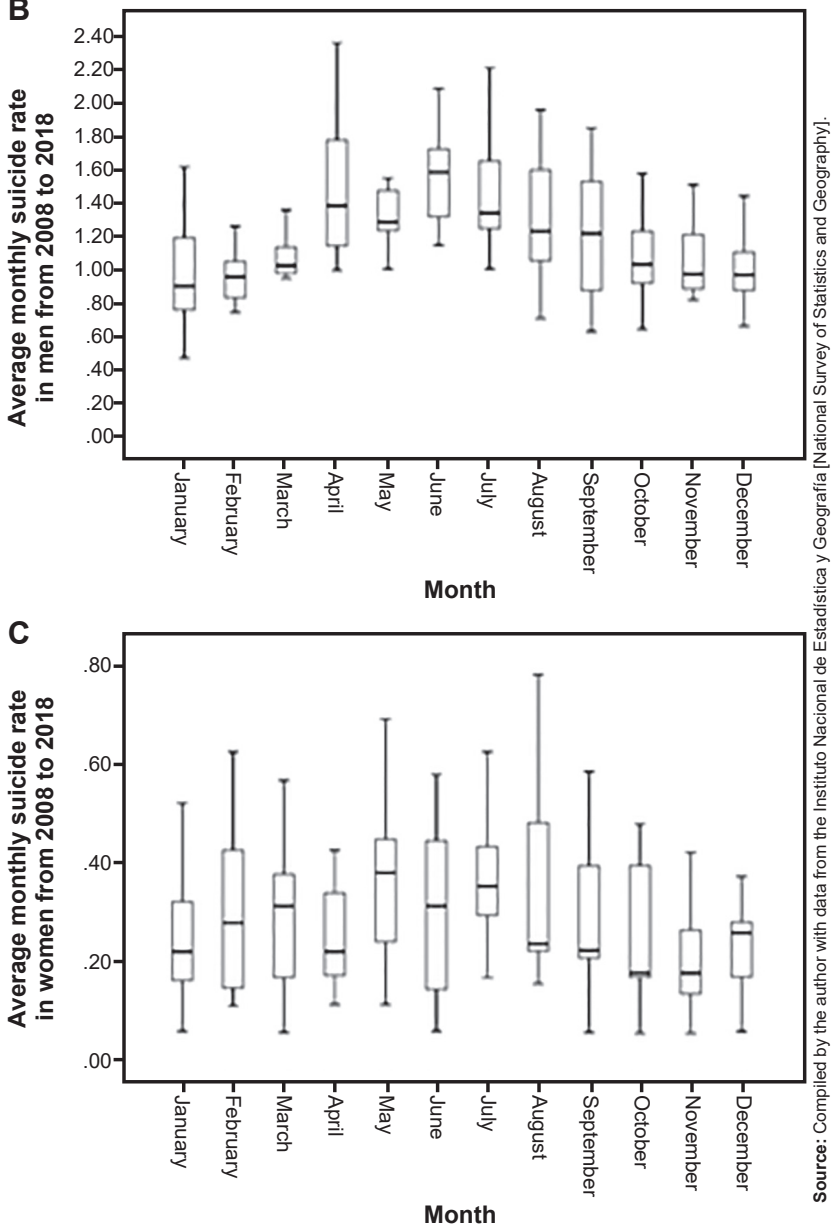

Figure 3. Average monthly suicide rate (per 100,000 inhabitants) from 2008 to 2018 in the state of Chihuahua. A) Total, B) Men, C) Women.

Gómez Castro (2014) observed increases in the suicide rate from 1970 to 1991 for the two sexes combined in Mexico.

This trend has also been accompanied by the seasonal factor. The present article observed that June and July are the months with the highest suicide rates. In fact, this behavior was exponential. From October to March, suicide rates were lower, and began to rise in April. The ambient temperature was associated with this seasonal behavior since temperatures in the summer and winter months are extreme in the state of Chihuahua. These results are consistent with the findings of Fernández-Niño et al. (2016), who found that May was the month with the highest frequency of suicides in Mexico from 2000 to 2013. A recent study analyzed the behavior of suicide in the state of Baja California Sur from 1985 to 2008, observing a sharp increase in suicide rates during the hot season (months with an average temperature of over $30^{\circ} \mathrm{C}$ ), together with an association between temperature and suicide rates (Gaxiola-Robles, Celis de la Rosa, Labrada-Martagón, Díaz-Castro, \& Zenteno-Savín, 2013).

A monthly temperature rise of $1^{\circ} \mathrm{C}$ has been found to be associated with an increase in suicide rates. Between 1968 and 2004, suicide rates in the United States increased by $.68 \%$ and between 1990 and 2010, they increased by $2.1 \%$ in Mexico for each degree centigrade of temperature increase (Burke et al., 2018).

In India, Carleton (2017) reported that with temperatures of $20^{\circ} \mathrm{C}$ and over, a $1{ }^{\circ} \mathrm{C}$ increase was associated with a 3.5\% increase in suicide rates during the harvest season. Similar results have been obtained in Italy (Muccino et al., 2015) and Canada (Dixon et al., 2014).

In a study undertaken in 29 European countries using a regression analysis with data on completed suicides from 2000 to 2012, Fountoulakis et al. found that climate variables explained $37.6 \%$ of the variance in suicide rates in men and $65 \%$ when combined with socio-economic variables. Conversely, in women, climate variables alone explained $28.1 \%$ of the variance in suicide rates, and $41.7 \%$ when socio-economic variables were added (Fountoulakis et al., 2016).

Some studies have attempted to explain the phenomenon of suicide associated with temperature in greater depth. A recent systematic review undertaken on people with suicide attempts in rural areas found that in five studies, summer water shortages were associated with high stress levels and suicide attempts due, for example, to reduced services, lower land values, and unemployment (Crnek-Georgeson, Wilson, \& Page, 2017).

Other studies have observed a directly proportional relationship between suicide rates and solar radiation adjusted by geographical area, humidity, temperature (Jee et al., 2017), and air pollution, particularly ozone $\left(\mathrm{O}_{3}\right)$ and dust $\left(\mathrm{PM}_{10}\right)$ particles (Casas et al., 2017; Chen \& Samet, 2017). $\mathrm{PM}_{10}$ contains large amounts of lipopolysaccharides, which are associated with depression and cytosine expression (Tonelli, Holmes, \& Postolache, 2008; Postolache, Manalai, Brenner, \& Brundin, 2016). However, since the literature is still limited, it is necessary to continue carrying out and developing these lines of research, addressing mainly neurophysiological factors and studies with qualitative approaches associated with the seasonality of the suicide phenomenon during the spring and summer seasons. 
Table 4

Poisson regression model between temperature and number of suicides completed from 2008 to 2018 in the state of Chihuahua by sex

\begin{tabular}{|c|c|c|c|c|c|c|c|c|c|}
\hline & \multirow{2}{*}{\multicolumn{2}{|c|}{ Omnibus contrast }} & \multirow{3}{*}{$\begin{array}{l}\text { Mean (standard } \\
\text { deviation) of sui- } \\
\text { cides per month }\end{array}$} & \multicolumn{6}{|c|}{ Model } \\
\hline & & & & \multirow[b]{2}{*}{ Parameter } & \multirow[b]{2}{*}{ B Coefficient } & \multirow{2}{*}{$\begin{array}{l}\text { Standard } \\
\text { error }\end{array}$} & \multirow[b]{2}{*}{ B Exponent } & \multirow{2}{*}{\multicolumn{2}{|c|}{$\begin{array}{l}95 \% \text { Wald Confidence } \\
\text { Interval of B exponent }\end{array}$}} \\
\hline & Chi squared & $p$ & & & & & & & \\
\hline \multirow[t]{2}{*}{ Both sexes } & 80.119 & .001 & $27.1(8.7)$ & Intersection & 2.769 & .0631 & 15.947 & 14.092 & 18.047 \\
\hline & & & & Temperature $\left({ }^{\circ} \mathrm{C}\right)$ & .028 & .0031 & 1.028 & 1.022 & 1.034 \\
\hline \multirow[t]{2}{*}{ Men } & 68.082 & .001 & $21.7(6.9)$ & Intersection & 2.537 & .0705 & 12.637 & 11.006 & 14.51 \\
\hline & & & & Temperature $\left({ }^{\circ} \mathrm{C}\right)$ & .028 & .0035 & 1.029 & 1.022 & 1.036 \\
\hline \multirow[t]{2}{*}{ Women } & 12.006 & .001 & $5.2(2.9)$ & Intersection & 1.203 & .1417 & 3.329 & 2.522 & 4.395 \\
\hline & & & & Temperature $\left({ }^{\circ} \mathrm{C}\right)$ & .024 & .007 & 1.024 & 1.01 & 1.039 \\
\hline
\end{tabular}

Another relevant finding in this study was the linear increase in suicide rates from 2008 to 2011 in women aged 10 to 34 and in men aged 10 to 44 in the state of Chihuahua, which suggests that this group should be a focus of attention, particularly women, since the group ages 10 to 24 had the highest suicide rates, whereas in men, rates were highest in the group ages 25 to 34 years and 65 years and over. A nationwide study by Borges et al. (2010) in Mexico observed an increase in suicide rates between the ages of 15 and 34 from 1970 to 2007 . Women aged 15 to 24 and men aged 20 to 34 and 65 and over recorded the highest suicide rate. These results coincide with the findings of the present study in the state of Chihuahua. They also complement the WHO statement that the prevalence and incidence of suicide in recent decades has represented the second leading cause of death among those ages 15 to 19 (WHO, 2018b).

In the United States, according to the Centers for Disease Control and Prevention (CDC), between 2007 and 2015 , suicide rates in women aged 15 to 19 years doubled from 2.4 to 5.1, while suicide rates for 2015 were the highest for the past 40 years (CDC, 2017).

In Mexico, Fadel et al. (2019) observed an increase in suicide rates in the population aged 10 to 14 years from 2000 to 2009 in both sexes, with annual increases of $2.8 \%$

Table 5

Number of suicides per age group and sex in the state of Chihuahua 2008-2018

\begin{tabular}{|c|c|c|c|c|c|c|}
\hline \multirow{2}{*}{$\begin{array}{l}\text { Five year } \\
\text { age cohort }\end{array}$} & \multicolumn{2}{|c|}{ Men } & \multicolumn{2}{|c|}{ Women } & \multicolumn{2}{|c|}{ Total } \\
\hline & Suicides & Rate & Suicides & Rate & Suicides & Rate \\
\hline $10-24$ years & 784 & 14.2 & 281 & 5.7 & 1065 & 9.8 \\
\hline $25-34$ years & 634 & 20.8 & 131 & 4.1 & 765 & 12.3 \\
\hline $35-44$ years & 524 & 19.7 & 125 & 4.5 & 649 & 11.9 \\
\hline $45-54$ years & 363 & 17.4 & 90 & 4.1 & 453 & 10.6 \\
\hline $55-64$ years & 218 & 16.9 & 38 & 2.7 & 256 & 9.6 \\
\hline $65-74$ years & 170 & 24.0 & 14 & 1.8 & 184 & 12.2 \\
\hline $75+$ years & 118 & 31.8 & 7 & 2.0 & 125 & 15.4 \\
\hline
\end{tabular}

Note: Suicide rate adjusted by sex and age for every 100,000 inhabitants. Source: Compiled by the author with data from the Instituto Nacional de Estadística y Geografía [National Survey of Statistics and Geography]. in suicide rates from 2005 to 2016. At the same time, Borges et al. (2010) found a $275 \%$ increase in suicide rates in the population ages 15 to 29 years between 1970 and 2007. This undoubtedly constitutes a challenge and a public health problem nationwide.

This study also found that suicide prevalence is four times higher in men than women, which coincides with what has been reported in the national literature (Fernández-Niño et al., 2016). However, worldwide, the male-tofemale ratio of suicides is $2: 1$, with an average suicide rate of 13.5 and 7.7 respectively, whereas in the Americas. the suicide rate in men is 15.1 and 4.6 in women, a ratio of 3.3:1 (WHO, 2018a).

One of the main limitations of this study was obtaining suicide data from records in the INEGI database, which may contain errors in the time when deaths were recorded, or the data provided or underreport completed suicides. However, it is one of the main official data sources. To date, no study has been found that evaluates this underreporting and inaccuracies in the information recorded. Another significant limitation of the present study was that average temperatures were obtained at the state rather than the municipal level. However, the statistical analysis performed did not enable us to record temperatures by municipality. This is particularly important in the state of Chihuahua, which has an extremely diverse climate in terms of its regions.

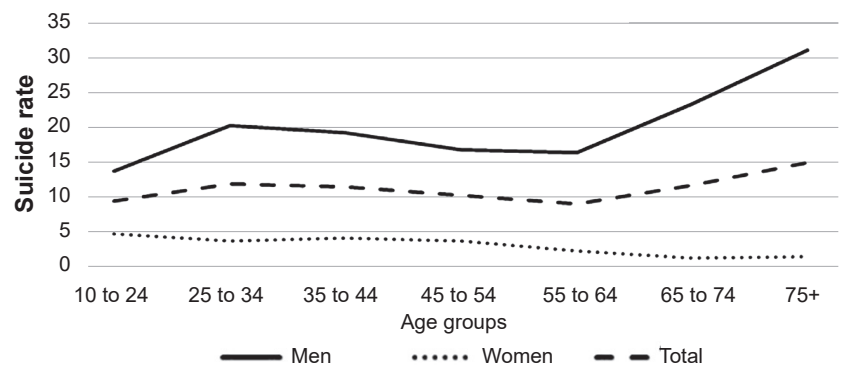

Figure 4. Suicide rate adjusted by age and sex (per 100,000 inhabitants) in relation to age groups from 2008 to 2018 in the state of Chihuahua.

Source: Compiled by the author with data from the Instituto Nacional de Estadística y Geografía [National Survey of Statistics and Geography]. 

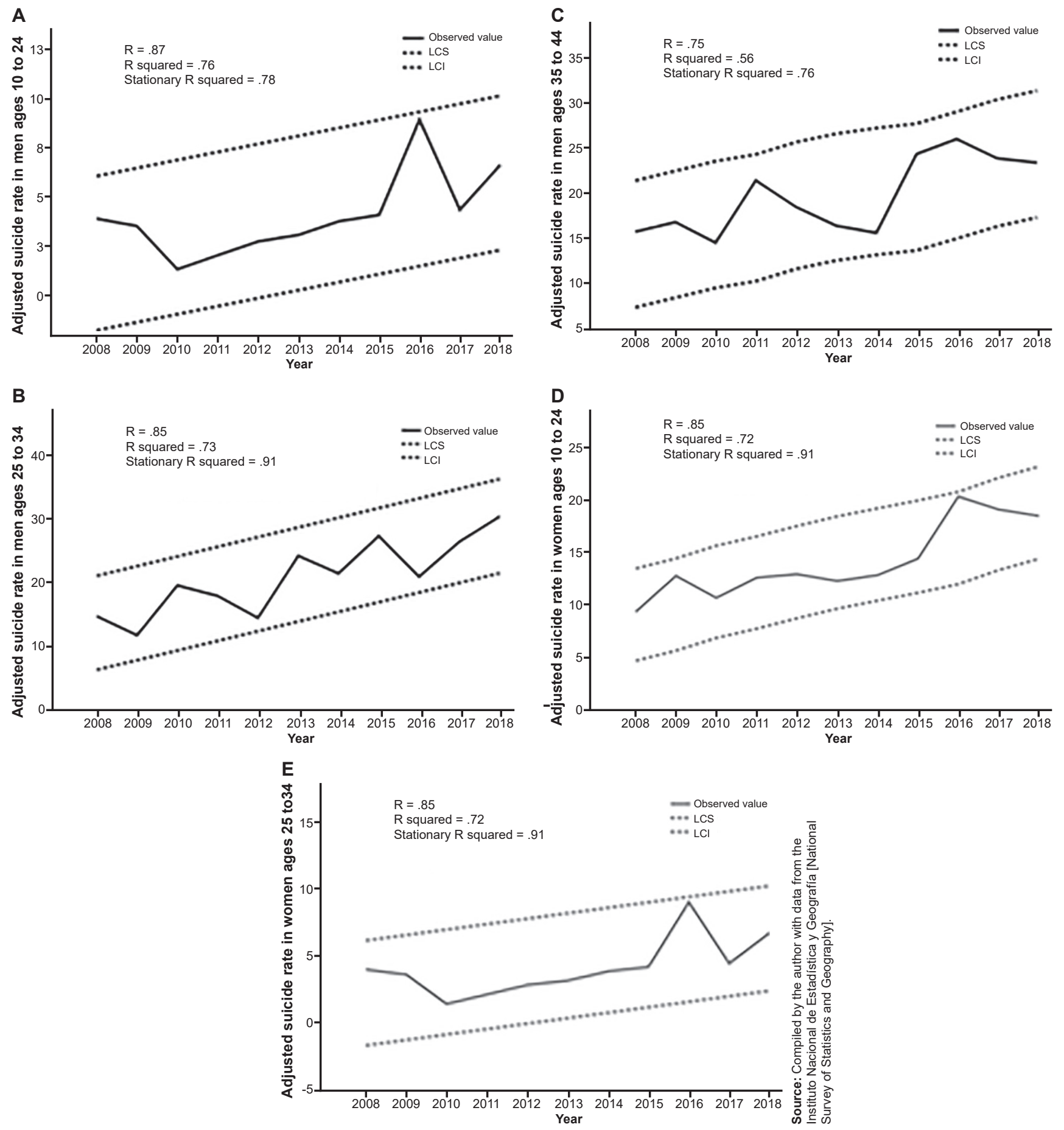

Figure 5. Linear trend in suicide rates (per 100,000 inhabitants) adjusted by age group and sex from 2008 to 2018 in the state of Chihuahua. A) Men aged 10 to 24, B) Men aged 25 to 34, C) Men aged 35 to 44, D) Women aged 10 to 24 and E) Women aged 25 to 34. 95\% Confidence intervals.

In conclusion, suicide rates in the state of Chihuahua displayed a trend and seasonal variability from 2008 to 2018 , with the months of June and July showing the highest suicide rates. This increase has occurred mainly among the young population aged 10 to 34 . The seasonal factor of suicide found in this research, together with the high suicide rates, suggest the need to rethink plans and strategies for suicide prevention in the state of Chihuahua. It is important to undertake more studies to analyze the epidemiological behavior of suicide in the state and its relationship 
with socioeconomic, sociodemographic, sociocultural, and environmental factors, because the evidence is still limited. This would facilitate the identification of the evolution of this phenomenon and the main associated risk factors, to develop more effective prevention and care strategies.

\section{Funding}

None.

\section{Conflict of Interest}

The authors declare they have no conflicts of interest.

\section{REFERENCES}

Ajdacic-Gross, V., Bopp, M., Ring, M., Gutzwiller, F., \& Rossler, W. (2010). Seasonality in suicide-A review and search of new concepts for explaining the heterogeneous phenomena. Social Science \& Medicine, 71(4), 657-666. doi: 10.1016/j.socscimed.2010.05.030

Bachmann, S. (2018). Epidemiology of suicide and the psychiatric perspective. International Journal of Environmental Research and Public Health, 15(7), 1425. doi: 10.3390/ijerph15071425

Borges, G., Orozco, R., Benjet, C., \& Medina-Mora, M. (2010). Suicidio y conductas suicidas en México: retrospectiva y situación actual. Salud Pública de México, 52(4), 292-304

Borges, G., Orozco, R., Villatoro, J., Medina-Mora, M. E., Fleiz, C., \& Díaz-Salazar, J. (2019). Suicide ideation and behavior in Mexico: Encodat 2016. Salud Pública de México, 61(1), 6-15. doi: 10.21149/9351

Borges, G., Rosovsky, H., Caballero, M. A., \& Gómez Castro, C. (2014). Evolución reciente del suicidio en México: 1970-1991. Available at https://scholar.google. com $/$ scholar?hl=es\&as_sdt $=0 \% 2 \mathrm{C} 5 \& \mathrm{q}=$ Evoluci $\% \mathrm{C} 3 \% \mathrm{~B} 3 \mathrm{n}+$ reciente $+\mathrm{del}+$ suic idio+en+M\%C3\%A9xico\%3A+1970-1991.\&btnG=

Burke, M., González, F., Baylis, P., Heft-Neal, S., Baysan, C., Basu, S., \& Hsiang, S. (2018). Higher temperatures increase suicide rates in the United States and Mexico. Nature Climate Change, 8(8), 723-729. doi: 10.1038/s41558-018-0222-x

Carleton, T. A. (2017). Crop-damaging temperatures increase suicide rates in India. Proceedings of the National Academy of Sciences, 114(33), 8746-8751. doi: 10.1073/pnas.1701354114

Casas, L., Cox, B., Bauwelinck, M., Nemery, B., Deboosere, P., \& Nawrot, T. S. (2017). Does air pollution trigger suicide? A case-crossover analysis of suicide deaths over the life span. European Journal of Epidemiology, 32(11), 973-981. doi: $10.1007 /$ s10654-017-0273-8

Centers for Disease Control and Prevention [CDC]. (2017). QuickStats: Suicide Rates for Teens Aged 15-19 Years, by Sex - United States, 1975-2015. Morbidity and Mortality Weekly Report, 66(30), 816. doi: 10.15585/mmwr.mm6630a6

Chen, J.-C., \& Samet, J. M. (2017). Air pollution and suicide risk: another adverse effect of air pollution? European Journal of Epidemiology, 32(11), 943-946. doi: 10.1007/s10654-017-0329-9

Comisión Nacional de Agua y Saneamiento [CONAGUA]. (2020). Información Estadística Climatológica. Retrieved from https://smn.conagua.gob.mx/es/ climatologia/informacion-climatologica/informacion-estadistica-climatologica

Crnek-Georgeson, K., Wilson, L. A., \& Page, A. (2017). Factors influencing suicide in older rural males: a review of Australian studies. Rural \& Remote Health, 17(4), 4020. doi: 10.22605/RRH4020

Dixon, P. G., Sinyor, M., Schaffer, A., Levitt, A., Haney, C. R., Ellis, K. N., \& Sheridan, S. C. (2014). Association of weekly suicide rates with temperature anomalies in two different climate types. International Journal of Environmental Research and Public Health, 11(11), 11627-11644. doi: 10.3390/ijerph111111627

Fadel, S. A., Boschi-Pinto, C., Yu, S., Reynales-Shigematsu, L. M., Menon, G. R., Newcombe, L., ... Jha, P. (2019). Trends in cause-specific mortality among children aged 5-14 years from 2005 to 2016 in India, China, Brazil, and Mexico: an analysis of nationally representative mortality studies. The Lancet, 393(10176), 1119-1127. doi: 10.1016/ S0140-6736(19)30220-X
Fernández-Niño, J. A., Astudillo-García, C. I., Bojorquez-Chapela, I., MoralesCarmona, E., Montoya-Rodriguez, A. A., \& Palacio-Mejia, L. S. (2016). The Mexican cycle of suicide: A National Analysis of Seasonality, 2000-2013. PloS One, 11(1), e0146495. doi: 10.1371/journal.pone.0146495

Fountoulakis, K. N., Chatzikosta, I., Pastiadis, K., Zanis, P., Kawohl, W., Kerkhof, A. J., ... Bech, P. (2016). Relationship of suicide rates with climate and economic variables in Europe during 2000-2012. Annals of General Psychiatry, 15(1), 1-6. doi: 10.1186/s12991-016-0106-2

Gaxiola-Robles, R., Celis de la Rosa, A. J., Labrada-Martagón, V., Díaz-Castro, S. C., \& Zenteno-Savín, T. (2013). Incremento de la temperatura ambiental y su posible asociación al suicidio en Baja California Sur (BCS) 1985-2008. Salud Mental, 36(5), 421-427. doi: 10.17711/SM.0185-3325.2013.053

Instituto Nacional de Estadística y Geografía [INEGI]. (2001). Estadísticas de mortalidad Instituto Nacional de Estadística, Geografia e Infor-mática INEGI. Retrieved from http://www.inegi.org.mx/est/contenidos/Proyectos/registros/ vitales/consulta.asp?c=11800\&s=est 23

Instituto Nacional de Estadística y Geografía [INEGI]. (2018). Estadísticas a propósito del dia mundial para la prevención del suicidio. Retrieved from https://www. inegi.org.mx/contenidos/saladeprensa/aproposito/2018/suicidios2018_Nal.pdf

Jee, H.-J., Cho, C.-H., Lee, Y. J., Choi, N., An, H., \& Lee, H.-J. (2017). Solar radiation increases suicide rate after adjusting for other climate factors in South Korea. Acta Psychiatrica Scandinavica, 135(3), 219-227. doi: 10.1111/acps.12676

Kalkstein, A. J., Belorid, M., Dixon, P. G., Kim, K. R., \& Bremer, K. A. (2019). Seasonal Variations in Temperature-Suicide Associations across South Korea. Weather, Climate, and Society, 11(4), 731-739. doi: 10.1175/ WCAS-D-19-0019.1

McMichael, A. J., Woodruff, R. E., \& Hales, S. (2006). Climate change and human health: present and future risks. The Lancet, 367(9513), 859-869. doi: 10.1016/ S0140-6736(06)68079-3

Muccino, E., Crudele, G. D. L., Gentile, G., Marchesi, M., Rancati, A., \& Zoja, R. (2015). Suicide drowning in the non-coastal territory of Milan. International Journal of Legal Medicine, 129(4), 777-784. doi: 10.1007/s00414-014-1115-9

Page, L. A., Hajat, S., \& Kovats, R. S. (2007). Relationship between daily suicide counts and temperature in England and Wales. The British Journal of Psychiatry, 191(2), 106-112. doi: 10.1192/bjp.bp.106.031948

Postolache, T. T., Manalai, P., Brenner, L. A., \& Brundin, L. (2016). Inflammation and suicidal behavior. Advances in Biological Psychiatry, 30, 123-144. doi: $10.1159 / 000434746$

Shah, A. (2007). The relationship between suicide rates and age: an analysis of multinational data from the World Health Organization. International Psychogeriatrics, 19(6), 1141-1152. doi: 10.1017/S1041610207005285

Shah, A. (2012). Suicide rates: age-associated trends and their correlates. Journal of Injury and Violence Research, 4(2), 79-86. doi: 10.5249/jivr.v4i2.101

Shah, A., \& Coupe, J. (2009). A comparative study of elderly suicides in England and Wales, Scotland and Northern Ireland: trends over time and age-associated trends. International Psychogeriatrics, 21(3), 581-587. doi: 10.1017/ S1041610209008515

Swade, C., \& Coppen, A. (1980). Seasonal variations in biochemical factors related to depressive illness. Journal of Affective Disorders, 2(4), 249-255. doi: 10.1016/0165-0327(80)90026-9

Tonelli, L. H., Holmes, A., \& Postolache, T. T. (2008). Intranasal immune challenge induces sex-dependent depressive-like behavior and cytokine expression in the brain. Neuropsychopharmacology, 33(5), 1038-1048. doi: 10.1038/ sj.npp. 1301488

World Health Organization [WHO]. (2018a, April 05). World Health Statistics data visualizations dashboard: Suicide. Geneva Switzerland: World Health Organization. Retrieved from http://apps.who.int/gho/data/node.sdg.3-4-viz2?lang=en

World Health Organization [WHO]. (2018b). Suicide. Geneva Switzerland: World Health Organization. Retrieved from https:/www.who.int/news-room/factsheets/detail/suicide 